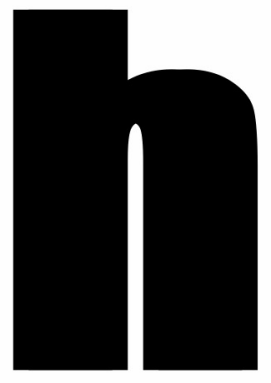

\title{
Jurnal Agraria dan Pertanahan
}

\section{Daftar Isi}

Pengantar Redaksi

Sejarah dan Revitalisasi Perjuangan Pertanian Nahdlatul Ulama Melawan Ketidakadilan Agraria Ahmad Nashih Luthfi 145-159

Konstruksi Mitos dan Kelokalan Sebagai Alat Eksklusi (Akses Masyarakat Lokal dan Imigran Terhadap SDA di Desa Lempur Kerinci-Jambi)

Dara Kartika Rahma 160-170

Esensi Sengketa Administrasi Pertanahan di

Peradilan Tata Usaha Negara Enrico Simanjuntak 171-188

Pola Adaptasi Ekologi Budaya Tiga Komunitas di Jambi Nana Kristiawan 189-200

Pola Keruangan Nilai Tanah di Kota Madiun Menggunakan Perspektif Ekonomi

Sudibyanung, Asih Retno Dewi, Harvini Wulansari 201-216
Implementasi Regulasi Tentang Surveyor Kadaster Berlisensi dalam Percepatan Pendaftaran Tanah Eko Budi Wahyono 217-231

Pengurangan Resiko Kebakaran Hutan dan Lahan Melalui Pemetaan HGU dan Pengendalian Pertanahan (Studi Kasus Provinsi Riau) Westi Utami, Arga Yugan Ndaru, Anggi Widyastuti, I Made Alit Swardiana 232-245

Peluruhan Kelembagaan Pertanian di Wilayah Periphery Perkotaan Tomi Setiawan, Haidar Adi M, Yames Pakniany, dan Indria R. Mutiar

246-266

Bentuk Pengelolaan Hutan Nagari Sungai Buluh Kabupaten Padang Pariaman Syofia Agustini, Arya Hadi Dharmawan, dan Eka Intan Kumala Putri

267-278

Review Buku: Mendistorsi Hegemoni dan AntiEsensialisme: Analisa "Mitos Tambang Untuk Kesejahteraan” dalam Kerangkeng Liberalisme ArifNovianto

279-285

\begin{tabular}{|c|c|c|c|c|c|}
\hline BHUMI & Volume 3 & Nomor 2 & $\begin{array}{c}\text { Halaman } \\
145-285\end{array}$ & $\begin{array}{c}\text { Yogyakarta } \\
\text { November 2017 }\end{array}$ & $\begin{array}{c}\text { ISSN 2442-6954 } \\
\text { E-ISSN 2580-2151 }\end{array}$ \\
\hline
\end{tabular}





\section{PENGANTAR REDAKSI}

Pada edisi kali ini kami menurunkan 10 artikel terpilih. Ahmad Nashih Luthfi menulis sejarah organisasi tani berbasis keagamaan dan kontekstualisasinya saat ini dihadapkan pada tantangantangan mutakhir. Ia menulis dalam judul "Sejarah dan Revitalisasi Perjuangan Pertanian Nahdlatul Ulama Melawan Ketidakadilan Agraria”. Uraian historisnya didasarkan pada telaah arsip dari ANRI dan dokumen militer. Penulis menjelaskan sejarah kelembagaan Pertanian Nahdlatul Ulama (Pertanu) dan perjuangannya dalam membela kaum tani pasca 1965, serta dinamika pelaksanaan landreform dan arus baliknya yang terjadi di Banyuwangi, Jawa Timur. Kontekstualisasi peran kelembagaan NU dalam memperjuangkan nasib petani ditunjukkan dengan keberadaan ormas keagamaan ini yang mengangkat isu reforma agraria sebagai salah satu topik Munas Nahdlatul Ulama 2017.

Dara Kartika Rahma menulis “Konstruksi Mitos dan Kelokalan Sebagai Alat Eksklusi (Akses Masyarakat Lokal dan Imigran Terhadap SDA di Desa Lempur Kerinci, Jambi)”. Ia menunjukkan strategi mempertahankan diri dengan cara menginklusi sekaligus mengeksklusi. Di tengah terganggunya mereka oleh program konservasi sehingga harus menerima kehilangan akses di area taman nasional yang sudah menjadi milik negara, mereka melakukan tindakan yang lebih protektif terhadap sisa lahan yang memang sudah digarap (inklusi). Di sisi lain, mereka melakukan eksklusi pihak-pihak luar (pendatang) yang juga ingin mengakses tanah. Keterbukaan mereka terhadap pendatang mulai pudar dan tidak mentoleransi pendatang untuk membuka lahan. Di sinilah mereka berstrategi dengan mengukuhkan konsep kelokalan dan merekonstruksi kembali mitos-mitos yang sangat kuat digaungkan untuk menahan laju pendatang, baik imigran, perusahaan, maupun wisatawan.
Perspektifdilematis diatas berlainan dengan situasi dimana masyarakat secara ideal mengakses tanah di wilayah hutan dalam konstruksi ulayat (hutan nagari). Masalah yang dihadapi oleh mereka adalah pada soal pengakuan. Ini yang digambarkan oleh Syofia Agustini, Arya Hadi Dharmawan, dan Eka Intan Kumala Putri, tatkala ia mengulas Hutan Nagari Sungai Buluh di Sumatera Barat. Penulis menyajikan artikel berjudul, "Bentuk Pengelolaan Hutan Nagari Sungai Buluh Kabupaten Padang Pariaman”. Pengakuan legalitasnya diperlukan terutama dalam konteks lahirnya kebijakan pemerintah melalui Peraturan Menteri Lingkungan Hidupdan Kehutanan RI No. P.83 Tentang Perhutanan Sosial.

Topik tentang bentuk-bentuk tenurial yang dilakukan oleh masyarakat melalui sistem yang mereka kembangkan sendiri juga disajikan oleh Nana Kristiawan dalam artikelnya, "Pola Adaptasi Ekologi Budaya Tiga Komunitas di Jambi”. Pola adaptasi ekologi budaya ketiga komunitas di Jambi yang penulis kaji menunjukkan keragaman dalam proses pencarian penghidupan. Penulis menyimpulkan bahwa masyarakat Talang Mamak yang dikaji menunjukkan cara bernafkah hunting and gathering, sedangkan masyarakat pendatang Jawa bekerja di hutan sebagai pembalak kayu. Perbedaan cara beradapatasi dari tiap kelompok masyarakat menunjukkan proses menuju kestabilan nafkah yang berbeda. Sedangkan stabilitas ekonomi rumahtangga Pendatang Melayu dinilai memiliki daya adaptasi rumahtangga terhadap lingkungan yang lebih tinggi sehingga struktur pendapatan dan tingkat kelentingannya yang jauh lebih baik dibandingkan dua kelompok masyarakat yang lain.

Perubahan masyarakat dan tingkat adaptasinya sangat tergantung pada perubahan lingkungan dan konteks agraria di sekitarnya. Jika beberapa artikel di atas menjelaskan konteks masyarakat agraria di 
dalam atau pinggiran perkebunan dan kehutanan, maka artikel Tomi Setiawan, Haidar Adi M, Yames Pakniany, dan Indria R. Mutiar ini menyajikan perubahan masyarakat di konteks kawasan pedesaan-perkotaan, atau sering disebut sebagai periferi. Penulis menggunakan pendekatan kualitatif NVivo serta pendekatan kuantitatif untuk mengukur korelasi Spearman Rank melalui metode SPSS. Artikel berjudul "Peluruhan Kelembagaan Pertanian Di Wilayah Periphery Perkotaan" ini menunjukkan bahwa terjadi peluruhan kelembagaan pertanian di wilayah periphery perkotaan Kabupaten Bogor sebagai dampak dari meningkatnya alih fungsi lahan pertanian ke non-pertanian.

Perubahan fungsi atas tanah sebagaimana di Bogor juga dikaji dalam kasus di Madiun, terutama dampaknya terhadap nilai tanah yang ada. Hal ini disajikan oleh Sudibyanung, Asih Retno Dewi, dan Harvini Wulansari dalam artikel berjudul, "Pola Keruangan Nilai Tanah di Kota Madiun”.

Perubahan penggunaan tanah untuk berbagai kepentingan yang tidak terkendali dapat mengakibatkan bencana. Pembukaan kawasan hutan untuk kepentingan perkebunan sering menimbulkan bencana kebakaran. Topik ini tersaji dalam artikel yang ditulis oleh Westi Utami, Arga Yugan Ndaru, Anggi Widyastuti, dan I Made Alit Swardiana. Dalam artikel yang berjudul "Pengurangan Risiko Kebakaran Hutan dan Lahan Melalui Pemetaan HGU dan Pengendalian Pertanahan", penulis mengajukan penyusunan peta kerawanan bencana berdasarkan metode Composite Mapping Analysis (CMA) berdasarkan hubungan setiap faktor terhadap persentase titik api (hotspot).

Kami juga menurunkan tulisan mengenai kebutuhan tenaga pertanahan dalam melaksanakan berbagai agenda strategis di Kementerian Agraria dan Tata Ruang/ Badan Pertanahan RI. Eko Budi Wahyono menulis artikel berjudul, "Implementasi Regulasi tentang Surveyor Kadaster Berlisensi dalam Percepatan Pendaftaran Tanah di Kanwil BPN Provinsi Sumatera Utara”.
Kasus-kasus pertanahan memiliki dimensi hukum yang kompleks. Di dalamnya terdapat masalah-masalah hukum yang bersifat perdata, pidana, konstitusi hingga administrasi. Penyelesaian kasus pertanahan yang bersifat administrasi diselesaikan melalui Peradilan Tata Usaha Negara (PERATUN). Peradilan ini sering dipilih dibanding peradilan yang lain sehingga menempatkan seakanakan masalah pertanahan adalah masalah administrasi semata-mata. Ini dikaji oleh Enrico Simanjuntak dalam "Esensi Sengketa Administrasi Pertanahan di Peradilan Tata Usaha Negara”.

Dimensi pertanahan dan sumberdaya alamyang kompleks itulah yang juga tampak dalam konflik agraria antara masyarakat dan PT Semen Indonesia (SI) di Rembang, Jawa Tengah atas rencana ditetapkannya sebagian wilayah di pegunungan Kendeng sebagai lokasi eksploitasi kebutuhan semen. Di sini kami menurunkan resensi buku yang menyoroti mengenai perlawanan rakyat bersama jaringan aktivis untuk menolak pendirian pabrik semen tersebut. Masyarakat menilai bahwa aktifitas pabrik akan merusak lingkungan ekologi serta aktifitas pertanian masyarakat. Dalam buku yang lebih menyoroti sisi wacana (kesejahteraan) serta perjuangan politikini, disoroti bahwa pembangunan pabrik itu mengandung mitos-mitos kesejahteraan, yang dalam praktiknya hanya akan menguntungkan sekelompok kecil kepentingan, dan akan merusak kesejahteraan rakyatyang telah terbukti beraktifitas melalui pertanian serta dampak lingkungan lain yang serius. Arif Novianto menulis resensinya dengan judul, "Mendistorsi Hegemoni dan Anti-Esensialisme: Analisa 'Mitos Kesejahteraan untuk Tambang' dalam Kerangkeng Liberalisme"”.

Kami berterima kasih kepada para penulis yang telah berkontribusi dalam jurnal edisi ini, serta para reviewer yang memeriksanya secara seksama.

Kepada para pembaca kami ucapkan selamat menelaah. 